\title{
Cage Culture of Carps in Ox-Bow Lakes of Assam: A Case Study
}

\author{
Sarmah A, Bora S, Bania R and Biswas SP* \\ Department of Life Sciences, Dibrugarh University, India
}

Submission: February 28, 2017; Published: March 27, 2017

*Corresponding author: Biswas SP, Department of Life Sciences, Dibrugarh University, Assam 786 004, India, Tel: 09435033479 ; Fax: 0373 2370323; Email: spbsdu@gmail.com

\begin{abstract}
A demonstrative cage culture of commercially important fish species was carried out at Gelabeel in Golaghat District and Moridikhow beel in Sivasagar District of upper Assam during 2013-14 as a technology for enhancement of fish production as well as an alternative source of livelihood for the rural people. Five carp species viz., Labeo rohita, L, calbasu, L. gonius, Catla catla and Cirrhinus mrigala were taken as candidate species for 3 months trial culture. Rice bran and mustard oil cake blended in 1:1 ratio was given in pelleted form daily @3-5\% of aggregate body weight of fry. Percentage of fish recovery from a $2 \mathrm{~m}^{3}$ after 90 days was $71.67 \mathrm{in} \mathrm{first} \mathrm{trial} \mathrm{and} 86.67$ in second trials. The average growth increment for about 3 months was $114.8 \mathrm{~mm}$ and $131.6 \mathrm{~g}$ and the average growth increment per month was $38.26 \mathrm{~mm}$ and $43.86 \mathrm{~g}$. On an average, a profit of Rs 840/- per cage was recorded in 3 months. At Moridikhow also, all the species showed encouraging growth However, poaching is a major problem and community participation for development of cage culture has been suggested.
\end{abstract}

Keywords: Cage culture; Carps; Ox-bow lakes; Assam

\section{Introduction}

Assam is gifted with about 1400 wetlands (locally called as bee) of varying sizes, and innumerable homestead ponds and tanks with total water spread area of 3.91 lakh ha. In national perspective, Assam contributed about $2.78 \%$ of the country's total inland fish production and the per capita fish consumption in the state at present is $7.58 \mathrm{~kg} /$ year. In beel fisheries, the productivity is $173 \mathrm{~kg} / \mathrm{ha} / \mathrm{yr}$ against the potential of $1500 \mathrm{~kg} / \mathrm{ha} /$ yr and in case of pond \& tank fisheries, the productivity is 1800 $2000 \mathrm{~kg}$ against the potential of $5000 \mathrm{~kg} / \mathrm{ha} / \mathrm{yr}$. Therefore, the present level of productivity in all categories of water resources is much below the potential of the resources. The study aimed to investigate the possibilities of rearing commercially important carps in suitable low cost cages in beels and to popularize culture based fisheries among the fishermen.

\section{Experimental Design}

\section{Installation of cages in wetland water}

Fixed cages were used for fish culture. At Moridikhow, cages were of the size $3 \mathrm{~m} \times 1.5 \mathrm{~m} \times 1.5 \mathrm{~m}$. The frame of the cage, which was rectangular in shape, was made with locally available bamboo. Bamboo made walls was used to cover the cage from four sides and also from bottom side. A nylon hapa was fitted inside the cage which has only an opening at upper portion of one side. Two cages were installed in water by keeping their bottom part $0.5 \mathrm{~m}$ above the ground and upper part from water with the same distance. At Gelabeel, individual cage had the dimension of $2 \mathrm{~m}^{3}$ (2xlxlm).

\section{Stocking}

600 fingerlings were stocked @100 fingerlings $/ \mathrm{m}^{3}$ area of the cage. Six fish species were selected for cage culture which was rohu (Labeo rohita), catla (Gibelion catla), mrigal (Cirrhinus mrigala), bata (Labeo bata), calbasu (Labeo calbasu) and gonius (Labeo gonius).

\section{Feeding}

Rice bran with mustard oil cake in the ratio 1:1 was given inside the cage daily for one time in the morning. 250g feed/ cage/day was given to the fishes. At Gelabeel too, Locally available rice bran and mustard oil cake blended in 1:1 ratio is given inside the cage water @3-5\% of aggregate body weight of fingerlings. The feed in pelleted form were given twice daily at 8 am and $4 \mathrm{pm}$. occasionally, dry fish powder and vitamins were also mixed with pelleted feed. Length and weight of randomly sampled specimens were recorded at regular interval for assessing growth of the reared species. 
Results

Table 1: Cage culture experiment at Gelabeel.

First trial:

\begin{tabular}{|c|c|c|c|c|c|}
\hline Fish Species & No. Stocked & $\begin{array}{c}\text { Average Stocking } \\
\text { Length (mm) }\end{array}$ & $\begin{array}{c}\text { Average Stocking } \\
\text { Weight (gm) }\end{array}$ & $\begin{array}{c}\text { Average Length } \\
\text { (mm) after 90 Days }\end{array}$ & $\begin{array}{c}\text { Average wt (gm) } \\
\text { after 90 Days }\end{array}$ \\
\hline Labeo rohita & 32 & 83 & 4.5 & 198 & 127 \\
\hline L.calbasu & 23 & 97 & 8 & 219 & 145 \\
\hline L. gonius & 20 & 90 & 7 & 208 & 145 \\
\hline Gibelion catla & 27 & 84 & 5 & 188 & 132 \\
\hline Cirrhinus mrigala & 21 & 85 & 6 & 199 & 139 \\
\hline
\end{tabular}

\section{Second trial:}

\begin{tabular}{|c|c|c|c|c|c|}
\hline Fish Species & No. Stocked & $\begin{array}{c}\text { Average Stocking } \\
\text { Length } \mathbf{( m m )}\end{array}$ & $\begin{array}{c}\text { Average Stocking } \\
\text { Weight (gm) }\end{array}$ & $\begin{array}{c}\text { Average Length } \\
\text { (mm) after 90 Days }\end{array}$ & $\begin{array}{c}\text { Average wt (gm) } \\
\text { after 90 Days }\end{array}$ \\
\hline Labeo rohita & 22 & 90 & 6 & 205 & 140 \\
\hline L. calbasu & 17 & 81 & 5 & 194 & 130 \\
\hline L. gonius & 17 & 83 & 9.5 & 198 & 135 \\
\hline Gibelion catla & 29 & 95 & 9 & 217 & 142 \\
\hline Cirrhinus mrigala & 23 & 92 & 9 & 145 \\
\hline
\end{tabular}

\section{Third trial:}

\begin{tabular}{|c|c|c|c|c|c|}
\hline Fish Species & No. Stocked & $\begin{array}{c}\text { Average Stocking } \\
\text { Length (mm) }\end{array}$ & $\begin{array}{c}\text { Average Stocking } \\
\text { Weight (gm) }\end{array}$ & $\begin{array}{c}\text { Average Length } \\
\text { (mm) after 90 Days }\end{array}$ & $\begin{array}{c}\text { Average Weight } \\
\text { after 90 Days (gm) }\end{array}$ \\
\hline Labeo rohita & 19 & 85 & 4.5 & 200 & 129 \\
\hline L. calbasu & 14 & 92 & 8 & 211 & 136 \\
\hline L. gonius & 14 & 82 & 3.5 & 209 & 134 \\
\hline Gibelion catla & 20 & 97 & 10 & 220 & 146 \\
\hline Cirrhinus mrigala & 23 & 99 & 9 & 148 \\
\hline
\end{tabular}

In the first trial, initial length of fishes ranges between 40-65 $\mathrm{mm}$ and initial weight ranges between 1.1- 2 g. After 90 days, fishes are found with length ranges between 103-155 mm and weight ranges between 10-36g (Table 1). Gibelion catla has the highest length gain $(88 \pm 5.42 \mathrm{~mm})$ followed by Labeo bata (87.5 $\pm 5.4 \mathrm{~mm})$. Similarly, Labeo gonius has the highest weight gain $(28.8 \pm 5.37 \mathrm{~g})$ followed by Gibelion catla $(23.1 \pm 2.79 \mathrm{~g})$. In the second trial of cage culture, initial length of fishes was $40-60 \mathrm{~mm}$ which increased up to $113-165 \mathrm{~mm}$ after 90 days of rearing. Likewise, initial weight of the selected fish species was 1.3-2.6g and at the time of harvesting was 15-36g (Table 2). Labeo bata has the maximum length gain $(100.5 \pm 5.78 \mathrm{~mm})$ followed by Gibelion catla with a length gain of $92.5 \pm 5.55 \mathrm{~mm}$. However, as far as dimensional growth is concerned, maximum weight gain exhibited by Labeo gonius $(31.3 \pm 3.23 \mathrm{~g})$ followed by Gibelion catla $(26.3 \pm 2.96 \mathrm{~g})$.

Table 2: Average growth parameters after three trials.

\begin{tabular}{|c|c|c|c|c|c|c|c|}
\hline Fish Species & $\begin{array}{c}\text { Average } \\
\text { Stocking } \\
\text { Length (mm) }\end{array}$ & $\begin{array}{c}\text { Average } \\
\text { Stocking } \\
\text { Weight (gm) }\end{array}$ & $\begin{array}{c}\text { Average } \\
\text { Harvested } \\
\text { Length (mm) }\end{array}$ & $\begin{array}{c}\text { Average } \\
\text { Harvested } \\
\text { Weight (gm) }\end{array}$ & $\begin{array}{c}\text { Absolute } \\
\text { Growth (g) }\end{array}$ & RGR (g/day) & SGR (\%/ day) \\
\hline Labeo rohita & 86 & 5 & 201 & 132 & 127 & 0.28 & 1.57 \\
\hline L. calbasu & 90 & 7 & 208 & 137 & 130 & 0.2 & 1.42 \\
\hline L. gonius & 85 & 5 & 200 & 138 & 133 & 0.29 & 1.59 \\
\hline Gibelion catla & 92 & 8 & 198 & 140 & 132 & 0.18 & 1.37 \\
\hline $\begin{array}{c}\text { Cirrhinus } \\
\text { mrigala }\end{array}$ & 92 & 8 & 212 & 144 & 136 & 0.19 & 1.38 \\
\hline
\end{tabular}

Harvesting was done 90 days after installation of cages. Out of 600 fishes, 430 were recovered in the first cage. Percentage of fish recovery was 71.67. In the second cage, 520 fishes were recovered and percentage of fish recovery was 86.67 .

\section{Cage culture at gelabeel}

Selection of species and stocking density At Gelabeel, individual cage had the dimension of $2 \mathrm{~m}^{3}$ (2xlxlm). Five carp species viz., Labeo rohita, L, calbasu, L. gonius, Gibelion catla 
and Cirrhinus mrigala were taken as candidate species in this demonstration. A 90 days culture period was planned for all the trials for the grow-out of fishes in cages.

The result shows that absolute growth of mrigal (Cirrhinus mrigala) was better than the other species. The initial sizes of the fishes in the three trials ranged from $80 \mathrm{~mm}$ to $100 \mathrm{~mm}(3.5 \mathrm{~g}$ to $10 \mathrm{~g}$ ) with an overall average of $89.2 \mathrm{~mm}$ and $6.6 \mathrm{~g}$. The average size increased to $203.8 \mathrm{~mm}$ and $138.2 \mathrm{~g}$ after 3 months. The average growth increment for about 3 months was $114.8 \mathrm{~mm}$ and $131.6 \mathrm{~g}$. Thus the average growth increment per month was $38.26 \mathrm{~mm}$ and $43.86 \mathrm{~g}$. Relative growth rate (RGR) for Labeo rohita was $0.28,0.20$ for L. calbasu, 0.18 for G. catla, 0.19 for Cirrhinus mrigala and $0.29 \mathrm{~g} \mathrm{day}^{-1}$ for L. gonius). Specific growth rate (SGR) were found to be 1.57 for L. rohita, 1.42 for L. calbasu), 1.37 for G. catla, 1.38 for C. mrigala and $1.59 \%$ day $^{-1}$ for L. gonius during 90 days of culture period (Table 2). The average survival rate of fishes after three trials was found to be $72.9 \%$.

\section{Economics of cage culture}

The total cost of cage culture operation was Rs.4960/. The economics of cage culture at Gelabeel are given in Table 3.

Table 3: Economics of cage culture.

\begin{tabular}{|c|c|}
\hline Items & Cost (INR) \\
\hline Cost of cage construction & 1500.00 \\
\hline Cost of fingerlings & $190.00+170.00+150.00=510.00$ \\
\hline Cost of feeding & 1050.00 \\
\hline Labour cost & 900.00 \\
\hline Miscellaneous expenses & 1000.00 \\
\hline Total cost of cage culture & $\mathbf{4 9 6 0 . 0 0}$ \\
\hline
\end{tabular}

Income from the 3 months trial:

Total weight of recovered fishes $=33 \mathrm{~kg}$.

Total Income $=$ Rs. 5800.00

Cost benefit ratio: 1.17

\section{Discussion}

An experimental culture of fishes in cages conducted at Ghorajan beel, a vast derelict water body, near Guwahati in Assam [1]. Although cage fish culture elsewhere showed promising result in fish production; surprisingly it has not gained popularity in Assam except some sporadic experiment conducted by State Fisheries Dept. and NABARB in recent years.

Various reports suggested that survival and production of fish in cages dependent on water quality, stocking size and density of reared fishes. Survival rates varied from $94.8 \pm 1.7 \%$ to $98.0 \pm 1.3 \%$ in stocking density 150 and $100 \mathrm{~m}^{-3}$, respectively, and decreased slightly with increasing densities [2]. The results of our present investigation revealed that at the end of 90 days, all the five fish species gained an encouraging weight. In our case the Indian major carps, Labeo rohita, Labeo calbasu, Gibelion catla, Cirrhinus mrigala and Labeo gonius have shown $72.3 \%$ survivability after 90 days with an average growth of $38.2 \mathrm{~mm}$ and 31.46g / month when feeding @ 2-3\% of fish body weight. Although the stocked fish were all fingerling size, the relatively low rate of survival might be due to fluctuating water quality as well as anthropogenic disturbances at culture site as it was in close proximity of a temple ghat. As far as growth rate is concerned, the relative growth rate (RGR) and specific growth rate (SGR) of Gibelion catla (RGR 0.18g day ${ }^{-1} /$ SGR $1.37 \%$ day $\left.{ }^{1}\right)$ and Cirrhinus mrigala $\left(0.19 \mathrm{~g} \mathrm{day}^{-1} / \mathrm{SGR} 1.38 \%\right.$ day $\left.^{-1}\right)$ were found to be lower than Labeo rohita (RGR 0.28g day ${ }^{-1} /$ SGR 1.57 $\%$ day $^{-1}$ ) and Labeo gonius (RGR 0.29g day ${ }^{-1} /$ SGR $1.59 \%$ day ${ }^{1}$ ). From our observation it has been found that L. rohita and $L$. gonius exhibited highest growth after the three trial. However, better growth rate in case of Labeo rohita and less growth rate in Cirrhinus mrigala [3]. Cage culture experiments carried out by CIFRI at Allahabad [4] recorded fish production of $16 \mathrm{kgm}^{-2}$ in case of Cirrhinus mrigala while its polyculture with Gibelion catla and Labeo rohita gave production of only $2 \mathrm{kgm}^{-2}$. Another experiment was carried out with Tor khudree and Tor putitora and found net production of $2.77 \mathrm{kgm}^{-3}$ for Tor khudree and $3.31 \mathrm{kgm}^{-3}$ for Tor putitora [5]. The cost benefit ratio during the present trial was 1.17 which can be increased upto three to four times by increasing the culture period.

Although work on cage culture of fish is in its infancy in Assam, such culture systems have numerous advantages over the traditional pond culture and may become relatively more profitable practice. One of the reasons may be the cost variation of feed and construction materials discourage the entrepreneurs to go for cage culture. Poaching of fish from cages is another major concern. Nevertheless, based on the findings from cage culture trial, it can be said that Gelabeel offer a great potential for culture based fish production and self help groups of nearby areas should take up cage culture of carps/air-breathing fishes on a cooperative basis.

\section{References}

1. Dehadrai P, Pal RN, Choudhury M, Singh DN (1974) Observations on air breathing fishes in swamps in Assam. Journal of Inland Fisheries Society of India 6: 89-92.

2. Rahman MM, Islam MS, Halder GC, Tanaka M (2006) Cage culture of sutchi catfish, Pangasius sutchi (Fowler 1937): Effects of stocking density on growth, survival, yield and farm profitability. Aquaculture Research 37(1): 33-39.

3. Prakash S, Gupta RA (1986) Studies on the comparative growth rates of three major carps of the Govindgarh lake. Indian Journal of Fisheries 33(1): 45-53.

4. Vass KK (1990) Pen and cage culture in open waters. In: Sugunan VV, Bhaumik U (Eds): Technologies for Inland Fisheries development. Central Inland Fisheries Research institute, Barrackpore, pp. 93-101.

5. Kohli MPS, Ayyappan S, Langer RK, Ogale SN, Dube K, et al. (2005) In: Vass KK, Abidi AH, late Agarwal VP (Eds). Proceedings of National Seminar on Aquatic Resource Management in Hills. Cage culture of Mahseer, Tor khudree (sykes) and Tor putitora (Ham.) at valwan reservoir, Lonavala, Maharastra, India, 171-178. 
This work is licensed under Creative Commons Attribution 4.0 Licens

DOI: 10.19080/OFOAJ.2017.01.555573

\section{Your next submission with Juniper Publishers} will reach you the below assets

- Quality Editorial service

- Swift Peer Review

- Reprints availability

- E-prints Service

- Manuscript Podcast for convenient understanding

- Global attainment for your research

- Manuscript accessibility in different formats ( Pdf, E-pub, Full Text, Audio)

- Unceasing customer service

Track the below URL for one-step submission https://juniperpublishers.com/online-submission.php 